Kateryna Kompanets,

Ph.D. in Economics, Kyiv National University of Trade and Economics, 19, Kyoto str., Kyiv, 02156, Ukraine, ORCID: 0000-0002-7189-2355; ResearcherID: N-6002 - 2018

Oksana Avdan

Ph.D. in Economics, Kyiv National University of Trade and Economics, 19, Kyoto str., Kyiv, 02156, Ukraine, ORCID: 0000-0003-1868-4685

\title{
COMMUNICATIVE MANAGEMENT OF THE HOTEL BUSINESS ENTITY BRAND
}

The article discusses innovative approaches to promote a hotel business brand. The properties of brand creation are defined and the main negative and positive levers in brand formation are presented. Ways of brand promotion are suggested.

Keywords: brand, innovations, tourist market, hotel business, brand positioning.

Relevance of research topic.In the conditions of increasing competition and information overload of consumers, there is a need to create individuality and uniqueness at all levels of the company's offer. Starting with the analysis of marketing opportunities and threats, evaluation of competitive proposals, consumption needs and available niches, the corporate brand and corporate identity are being created, the strategy of the company'sdevelopment and its brand portfolio is formed. Therefore, in the current conditions of oversupply of the market with goods and services, the concept of branding, i.e. creating a positive image of companies - market participants, is becoming more widespread. Therefore, it is important to study and develop methods of brand formation and promotion.

Formulation of the problem. The issue of creating and promoting a brand of hotel and restaurant businesses is complex. Specificity of work of the enterprises of the hotel industry was studied by M.G. Boyko, L.M. Gopkalo, V.O. Lukyanov, G.B. Munin, O.G. Rosmetova, T.L. Mostenska, T.V. Vladarchik, T.G. Sokol, V.E. Stepanova and others.

Marketing and management aspects of relationships with consumers of the hotel and restaurant business are studied in the works of such authors as V.M. Maltseva, M.A. Blum, B.I. Gerasimov, N.V. Molotkova, F. Kotler, D.T. Bowen, 
D. Mackens, D.C. Mathew, S.A. Bury, S.V. Melnichenko, A.V. Magaletsky, V.S. Starostin, L.V. Tkachenko, etc. In spite of the considerable amount of scientific development on the investigated issues, a number of theoretical and practical questions remain insufficiently elaborated.

The purpose of the research is to substantiate theoretical and practical approaches to the use of innovative brand promotion technologies.

The basis of relationship marketing is an individual approach, where instead of focusing on selling the services of the hotel industry for a specific period of time to the maximum number of consumers, it is necessary to focus on each specific consumer and offer him more products that would be relevant to him. The idea of relationship marketing, driven by the heterogeneity of the consumer audience and the individuality of each client, can be realized by promoting the brand of the company.

In studies by F. Kotler, J. Bowen, and J. Mackenz [6, p. 592] the features and main characteristics of the goods and services that satisfy the customer and their lack are considered as the main indicators of quality. Agreeing with the authors, it should be noted that the decision to use the services of a particular hotel complex is made by consumers based on the values of certain marketing proposals, namely the brand of the company.

In agreement with the position of M.G. Boyko [1], V.O. Lukyanov [4], G.B. Munin [5], S.V. Melnichenko and A.V. Magaletsky [7], that in the hospitality industry, a personal approach to customer service is the main criteria for quality service, and the formation of a positive image through the promotion of the brand is one of the foundations of the hospitality industry.

Presenting main material.Consumer involvement, in this case, involves a personal form of conscious collaboration with the hotel business, expressed in actions to convey information, as well as in direct involvement in the process of creating consumer value. Therefore, creating new channels to promote and brand promotion at the current stage of hotel business development is an integral part of running a productive business. Innovative brand promotion channels are presented in Table 1.

The hotel and restaurant business is transformed under the influence of changes in consumer demand. In recent years, the development of the hospitality industry has been accompanied by a number of challenges for the industry, including an increase in the number of shared service providers, an increasing impact on the booking process of online travel agencies, and the rapidly changing needs and expectations of guests. That is why in order to ensure the profitability of the enterprises of the hotel and restaurant complex, it is important to move from the classic marketing paradigm of exchange of material goods between sellers and buyers to a new concept of relationships, where the fundamental purpose of marketing is to establish long-term relationships with each specific consumer. However, the values, preferences and expectations of consumers are not constant or universal. Consumers are beginning to 
rely on a personalized approach that addresses their individual needs. As a result, hotel businesses have to take into account these high expectations, which are set by companies in other industries. The main attributes of the hotel business brands are summarized in Table 2.

Table 1

\section{Innovative brand promotion technologies}

\begin{tabular}{|c|c|c|}
\hline № & Company & Characteristic \\
\hline 1 & TripAdvisor & $\begin{array}{l}\text { Chat Bot is a virtual interlocutor, an artificial intelligence program } \\
\text { that can communicate with live users via text message. As a rule, } \\
\text { chatbots are used as assistants for interaction, communication or } \\
\text { simply for the entertainment of users. } \\
\text { With the advent of the new feature, travelers can visit TripAdvisor via } \\
\text { Facebook Messenger to find out where to stay, which bar / restaurant } \\
\text { to choose, or what to do in your free time. TripAdvisor will instantly } \\
\text { review millions of reviews and provide you with a list of top } \\
\text { recommendations, all within the Facebook Messenger platform. In } \\
\text { addition, the chat bot will constantly explore the benefits of users to } \\
\text { form the perfect trip }\end{array}$ \\
\hline 2 & Travel Unwrapped & $\begin{array}{l}\text { The London-based startup invites tourists to take a journey to their } \\
\text { roots, the flagship product of DNA Unwrapped. } \\
\text { Allows you to track your origin in } 80 \text { regions of the world and offer } \\
\text { DNA-based travel. It's like creating a personalized world map that } \\
\text { lists places that matter personally to you }\end{array}$ \\
\hline 3 & $\begin{array}{l}\text { Starwood Hotels \& } \\
\text { Resorts Worldwide }\end{array}$ & $\begin{array}{l}\text { Guests of Four Points by Sheraton, Aloft and Elements will be able to } \\
\text { test and evaluate all the benefits of innovative technology in their } \\
\text { personal experience, including access to a room via smartphone or } \\
\text { Apple Watch, smart, forward-looking mirrors, butler services and a } \\
\text { number of other technologies. } \\
\text { Because the Four Points by Sheraton brand is focused mainly on } \\
\text { business audiences, Starwood experts have analyzed which services } \\
\text { and services in the hotel room are most popular with business } \\
\text { travelers }\end{array}$ \\
\hline 4 & NH Hotel Group & $\begin{array}{l}\text { Holding High Tech Made Easy Virtual Meetings and Events. The } \\
\text { solution has no analogues in the world, combines the multimedia } \\
\text { capabilities of the LED screen and the 3D effect of virtual presence }\end{array}$ \\
\hline 5 & Marriott & $\begin{array}{l}\text { A teleporter that allows you to instantly move to a luxurious hotel } \\
\text { room, find yourself on the roof of a skyscraper or hit the blue ocean. } \\
\text { The cabins are equipped with a special Oculus Rift DK2 headset and } \\
4 \mathrm{D} \text { touch elements that make it possible for those wishing to } \\
\text { «navigate» to feel the sea breeze, the heat of the tropical sun, the } \\
\text { rustle of leaves and even the fog }\end{array}$ \\
\hline
\end{tabular}




\section{Properties of hotel business entity brands}

\begin{tabular}{|l|l|}
\hline \multicolumn{1}{|c|}{ Positive branding } & \multicolumn{1}{c|}{ Negative branding } \\
\hline Designed to attract the buyer's attention & The desire to be a brand for all \\
\hline $\begin{array}{l}\text { The brand must be alliterative; this contributes } \\
\text { to their memorization }\end{array}$ & Attempt to build positioning at low cost \\
\hline $\begin{array}{l}\text { The brand must be related to the positioning } \\
\text { of the product on the map, consumer perception }\end{array}$ & $\begin{array}{l}\text { Attempting to reach another segment by the } \\
\text { linear extension method that results in positional } \\
\text { blurring }\end{array}$ \\
\hline $\begin{array}{l}\text { The brand should be associated with the visual } \\
\text { image }\end{array}$ & $\begin{array}{l}\text { The focus is not on brand features that truly } \\
\text { differentiate it from its competitors }\end{array}$ \\
\hline $\begin{array}{l}\text { The brand should carry some information about } \\
\text { the hotel product }\end{array}$ & $\begin{array}{l}\text { Excessive enthusiasm for «creativity» and } \\
\text { inappropriate marketing budget spending on } \\
\text { brand promotion }\end{array}$ \\
\hline Encourage you to create a nickname & Lack of communication with the consumer \\
\hline
\end{tabular}

Brand promotion in the market is a set of measures aimed at brand awareness, search for the target audience and promotion of the brand, which in a favorable light will show the importance of the brand and advantages over competitors (Fig. 1).

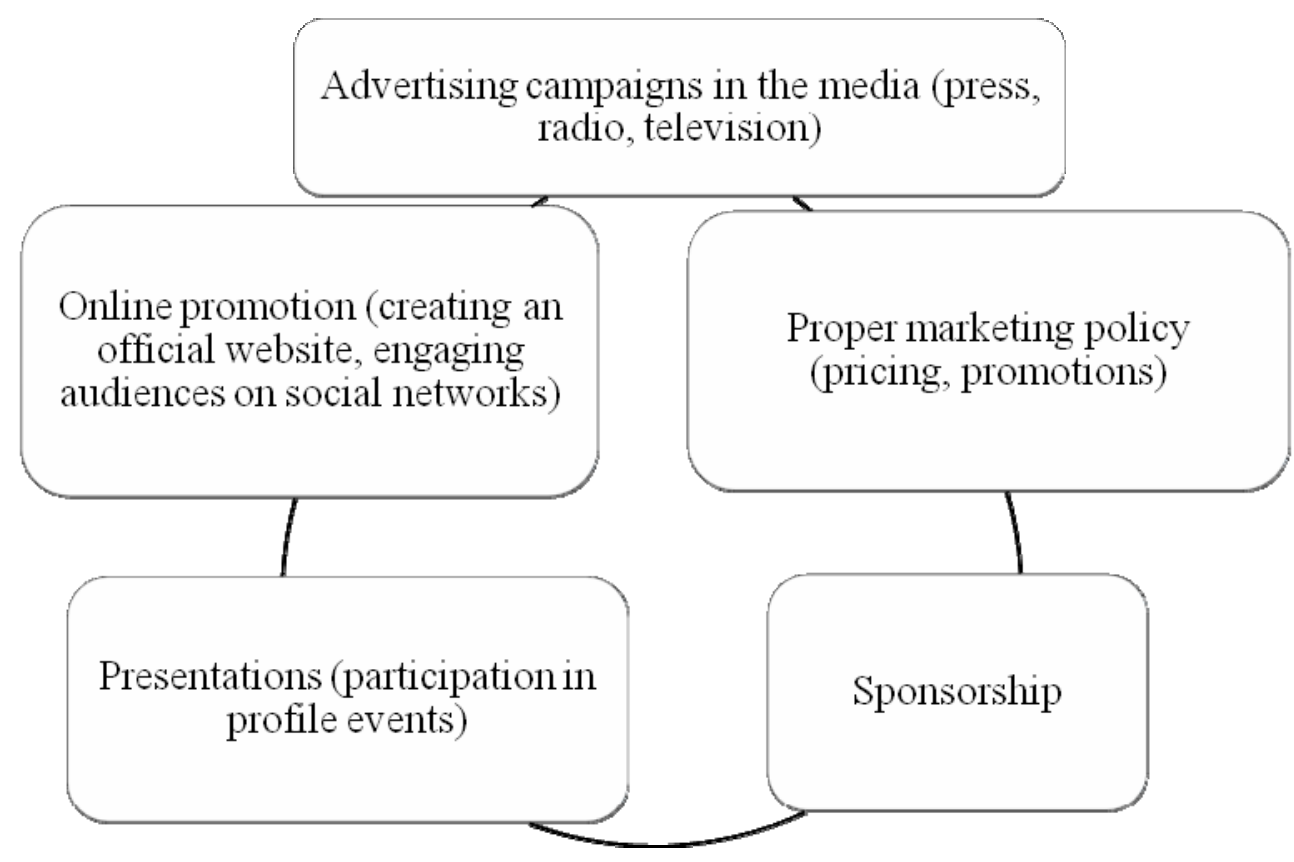

Fig. 1. Effective ways a brand promotion to the market

Source: copyright development

The ways of brand promotion mentioned in Figure 1 require financial investments. Before launching an advertising campaign, it is needed to consider its effectiveness. When choosing methods of promotion, take into account the human 
factor is the specificity of the target audience and the mentality of the people of the specific country or region, where the promotion of goods or services [8, p. 115].

The object of promotion in branding is the brand as a complex marketing system, which is used in modern business activities to create additional competitive advantages in a market where the product itself is one of the components of the marketing mix [9].

Internet space is simply the perfect environment for branding. After all, there is a target audience of any product and service that can be filtered in different ways - this process is called «targeting». On the Internet there is an opportunity to have a direct and open dialogue with their customers, answer their questions, promptly inform about any innovations or promotions that are taking place [3].

Among other things, brand promotion on the network can be carried out with significantly lower costs compared to offline promotion, or even without financial costs (depending on the methods chosen) [2].

Conclusion. Effective brand formation of the hotel business entity will allow to quickly overcome imbalances in individual market segments, replenish the budgets of different levels, stimulate innovation, develop competition and generate new jobs.

\section{REFERENCES}

1. Boyko, M., Hopkalo, L (2015) Hotel organization: electron. Textbook, Kiev: Kiev. nat. trading econ. Univ., p. 501.

2. Booking and promotion of hotels finally «goes» to the Internet Retrieved from: http://tourlib.net

3. Gerasimenko, V., Davydenko I. (2019) Internet as a means of promotion of tourist services Marketing in Ukraine., Vol. 2., p.p. 41-47. Retrieved from: http://ir.kneu.edu.ua

4. Lukyanov, V., Munin, G (2015) Organization of hotel and restaurant services: training. Tool., Kiev: Condor, $346 \mathrm{p}$.

5. Munin, G. (2017) Marketing of hotel and restaurant business: training. tool., Kiev: View of Europe. Univ., 246 p.

6. Kotler F., Bowen, D., Mackens D, (2018) Marketing. Hospitality. Tourism: A textbook for university students, 4th ed., Revised. and ext. - M.: UNITI-DANA, 1071 pp. (N): 70x100 1/16. - (Foreign textbook)

7. Melnichenko, S,.Magaletsky, A. (2018) Marketing policy in the hotel business: monograph, Kiev. nat. trading econ. Univ. - Kiev: Kiev. nat. trading econ. Univ, $343 \mathrm{p}$.

8. Primak, T. Marketing Communications: Educ. tool. / TO Primak. Elga, NikaCenter, Kiev, Ukraine. - $280 \mathrm{sec}$.

9. Principles of successful brand promotion. Mode of access to the resource: Retrieved from: https://studme.com.ua 